\title{
Histopathological alterations in psoroptic mange caused by Psoroptes cuniculi (Delafond, 1859) in goats
}

\author{
Alterações histopatológicas alterations in na sarna psoroptic \\ causada por Psoroptes cuniculi (Delafond, 1859) in caprinos
}

\author{
Malba Gean Rodrigues Amorim¹; Antônio Flávio Medeiros Dantas²; \\ Franklin Riet-Correa ${ }^{2 *}$
}

\begin{abstract}
With the aim to study the histologic lesions caused by Psoroptes cuniculi, the ears of 15 adult goats were collected in a slaughter house in the city of Patos, state of Paraíba, in the Brazilian semiarid region. Five goats had crusts and exudates in the external ears and were infested by 21 to 189 mites in each ear. Another 10 goats were asymptomatic, five of which had 14 to 39 mites and five of which were non-infested. From the five goats with clinical signs, three presented moderate macroscopic lesions with cerumen and dry crusts in both ears, affecting the pinna and ear canal. Two other goats presented mild lesions, characterized by exudates in the pinna without crust formation. The histologic lesions included varying degrees of parakeratotic hyperkeratosis, orthokeratotic hyperkeratosis, acanthosis, hypergranulosis, spongiosis, and dermatitis, with rare eosinophils. P. cuniculi were observed in the ear canal, occasionally in contact with the stratum corneum, but without causing traumatic lesions in the epithelium, which suggests that the lesions occur through a mechanical effect due to the presence of the mites together with the exudates, cerumen, and keratin residues.
\end{abstract}

Key words: Goats, Psoroptes cuniculi, otoacariasis

\section{Resumo}

Com o objetivo de estudar as lesões histológicas causadas por Psoroptes cuniculi, as orelhas de 15 caprinos adultos foram coletadas em um abatedouro da cidade de Patos, na região semiárida da Paraíba. Cinco caprinos apresentavam crostas e exsudato nas orelhas externas e estavam infectados por 21 a 189 P. cuniculi em cada orelha. Outros 10 caprinos eram assintomáticos; destes, cinco eram infectados com 14 a 39 ácaros e cinco não estavam infectados. Dos cinco caprinos com sinais clínicos, três apresentavam lesões macroscópicas moderadas com cerume e crostas secas no pavilhão auditivo e conduto auditivo externo. Outros dois caprinos apresentavam lesões leves com exsudato no pavilhão auditivo, sem crostas. Às lesões histológicas incluíram vários graus de hyperqueratose paraqueratótica, hyperqueratose ortoqueratótica, acantose, hypergranulose, espongiose, e dermatite, com raros eosinófilos. P. cuniculi foi observado no canal auditivo, ocasionalmente em contato com o estrato córneo, mas sem causar lesões traumáticas no epitélio, sugerindo que as lesões ocorrem por efeito mecânico devido à presença de ácaros junto com exsudato, cerume e resíduos de queratina.

Palavras-chave: Caprinos, Psoroptes cuniculi, sarna psoróptica

1 Discente, Programa de Pós-graduação em Medicina Veterinária. Universidade Federal de Campina Grande, UFCG, Patos, PB, Brasil. E-mail: malbita@ig.com.br

2 Profs., Programa de Pós-graduação em Medicina Veterinária. Hospital Veterinário, UFCG, Patos, PB, Brasil. E-mail: dantas.af@ uol.com.br; franklin.riet@pq.cnpq.br

* Author for correspondence 
Astigmatic mites of the Genus Psoroptes (Acari: psoroptidae) are obligatory ectoparasites that inhabit the body and the external ear of ruminants. The Psoroptes species in all the evolutionary stages are found feeding on the superficial epidermis on substances rich in lipids, lymph, epidermal cells and blood, determining the otoacariasis or psoroptic mange (SINCLAIR; KIRKWOOD, 1983).

In goats the psoroptic mange may be symptomatic or asymptomatic. In the symptomatic form the most common clinical sign is the presence of crusts and exudates in the external ears. Some severely infested animals may show intense itching, restlessness, shaking of the head, isolation from the herd, lateral inclination of the head, purulent yellow secretion, dry or humid crusts, and alopecia, which may extend from the base of the head to the cervical region (SANTOS; SANTOS; GUERRA, 2002). However, these severe signs are very rarely observed in the herds of the semiarid region, where the asymptomatic cases predominate.

Infestation with $P$. cuniculi in goats has been reported in different countries (LITTLEJOHN, 1968; MUNRO; MUNRO, 1980; HEATH; BISHOP; TENQUIST, 1983; YERUHAM; HADANI; ROSEN, 1985; FRIEL; GREINER, 1988; PERRUCCI et al., 1996), including Brazil (FACCINI; LIGNON; LEITE, 1981). The prevalence of infestations with $P$. cuniculi in the Brazilian semiarid region varies between 53\% and $73 \%$ in the states of Pernambuco, Bahia, Piauí (FACCINI; LIGNON; LEITE, 1981), Ceará (COSTA; VIEIRA, 1984), and Paraíba (SANTOS; SANTOS; GUERRA, 2002), but the economic losses caused by psoroptic mange in infested animals are unknown. Reports of histopathological alterations in psoroptic mange in goats are rare. A severe epidermal hyperplasia with marked cellular crusting (hyperkeratosis and inflammatory cells debris) and superficial eosinophilic perivascular dermatitis was reported in a Nubian doe infected by Psoroptes sp. with severe dermatitis of the face and trunk and external otitis (LOFSTEDT et al., 1994).
Therefore, the aim of this study was to describe the histopathological aspects of psoroptic mange in the ear of goats with different levels of infestations by P. cuniculi.

The study was performed with 15 adult goats, older that three years, crossbreeds, of both genders, with or without clinical signs of psoroptic mange, that were slaughtered in the Municipal Slaughter House in the city of Patos, state of Paraíba, northeastern Brazil. The sample of 15 goats was obtained at random over a population of 255 slaughtered goats. Clinical signs were evaluated before slaughter by the presence of crusts, exudate or excessive amounts of cerumen. The macroscopic lesions were classified according to Littlejohn (1968) as follows: a) mild: lesions containing crusts only in the pinna and outer (cartilaginous) ear canal; b) moderate: lesions associated with a great amount of cerumen and crusts and that extend from the inner (bony) ear canal to the apex of the external face of the pinna; c) severe: lesions distributed bilaterally, in both in the ear canal and the internal and external face of the pinna, extending from the head to the anterior limbs.

After each goat was slaughtered, the ears were washed with a water jet, and the recovered mites were preserved in 70\% alcohol, and then identified and quantified in accordance with Sweatman's taxonomic key (SWEATMAN, 1958). Then, the goats' ears were obstructed with cotton balls and the goats' heads were individually packed in plastic bags, identified, and transported to the Animal Pathology Laboratory, in the Veterinary Hospital of the Federal University of Campina Grande, where the ears were removed according to the technique described by Nunes and Nunes (1975). The external ears were fixed in a $10 \%$ formalin solution for 15 days. After the fixation, as much of the bone structures as possible were removed with the use of a manual saw, and the samples were decalcified in a solution of $10 \%$ formic acid and $15 \%$ sodium citrate for 25 days. 
After the decalcification, samples of the cartilaginous and bony portions of the ear canal were embedded in paraffin, sliced into sections of 4-6 $\mu \mathrm{m}$ and stained with hematoxylin-eosin.

Of the 15 investigated goats, five had exudates and/or crusts in the pinna and were infested by 21 to 189 mites in each ear. Another 10 goats were asymptomatic, five of which had 14 to 39 mites and five of which were non-infested. From the five goats with lesions, three presented moderate macroscopic lesions, characterized by the presence of cerumen and crusts with a dry consistency in the pinna and ear canal of both ears. Two other goats presented mild lesions, characterized by exudates in the pinna without crust formation.

In the three cases of moderate lesions, the histology revealed hyperplasic lesions, including varying degrees of parakeratotic hyperkeratosis, orthokeratotic hyperkeratosis, acanthosis, and hypergranulosis (Fig.1 A-D) In the epithelia there were necrotic cellular residues and degenerated neutrophils, sometimes forming intracorneal pustules (Fig 1C). Vacuolization of the keratinocytes and intercellular edema (spongiosis) were also observed (Fig.1A). Congestion and a mixed inflammatory infiltrate composed mainly of neutrophils, macrophages, lymphocytes, and plasma cells were present in the superficial and deep dermis (Fig 1 A-D). In two animals, rare eosinophils were observed, mainly around the vessels, while in one goat the infiltration by eosinophils was severe. One goat presented severe hyperplasia and hypertrophy of the sebaceous glands. Associated with these lesions, there were adult and young mites in the conduit surrounded by cerumen and keratin residues (Figure 1A, B, D). Some mites were free in the conduit and other mites were in contact with the stratum corneum but without causing obvious traumatic lesions in the epithelium (Fig.1A). In the two goats with mild gross lesions, moderate hyperplasic lesions of the epithelium and rare multifocal perivascular infiltrates in the epidermis and superficial dermis were observed. In the asymptomatic goats, with or without mites, only mild hyperplasic lesions of the epithelium were observed.

In this study, 5 of the 10 infested goats had no clinical signs. In the goats with clinical signs that had infestations of 21 to 189 mites per ear, the lesions were observed only in the ears. No cases of severe psoroptic mange were observed. In the asymptomatic animals, the number of mites recovered was up to 39 mites per ear, which suggests that the presence of clinical signs is determined by the number of mites present. Santos, Santos and Guerra (2002) suggests that in goats, an elevated infestation by $P$. cuniculi is an important factor determining the presence of clinical signs; but other factors, such as age, sex, physiological state (gestation), individual resistance and the host's nutritional state, as well as the herd management, may influence the occurrence of clinical signs (LITTLEJOHN, 1968; STROMBERG et al., 1986).

In the present experiment, it was verified in the histological study that $P$. cuniculi is found free in the ear canal, but even when the organism is in contact with the stratum corneum $P$. cuniculi does not cause significant traumatic or inflammatory lesions to the epithelium. Furthermore, mite penetration into the epithelium was not observed, most likely because this parasite does not have a digging habit, because $P$. cuniculi has a short gnathosoma and the chelicera are not adapted to cut the host's skin (SWEATMANN, 1958). The presence of P. cuniculi adhering to exudate and cerumen in the ear canal suggests a mechanical lesion, different from the lesions caused by Raillietia auris in bovines, which causes a traumatic lesion and may perforate the epithelium with the tarsus' clutches during fixation or with the gnathosoma's chelicera during feeding (FERRY; FACCINI; INADA, 2011). 
Figure 1. External ear of goats infected by P. cuniculi. A) Acanthosis (a), parakeratotic hyperkeratosis (hp), ortokeratotic hyperkeratosis (ho), espongiosis (e), and dermatitis (d) are observed. A mite (arrow) is in contact with the epithelium, but without causing lesions. H\&E, obj. 10. B) Ortokeratotic hyperkeratosis (ho), dermatitis (d), and the presence a mite (arrow) within a mass of cerumen and keratin are observed. H\&E, obj. 10. C) Parakeratotic hyperkeratosis (hp), ortokeratotic hyperkeratosis (ho), acanthosis (a), dermatitis (d), and a intracorneal pustule (pi) are observed H\&E, obj. 20. D) Numerous mites (arrows) are observed within a mass of cerume, keratin residues, and exudate. Ortokeratotic hyperkeratosis (ho), acanthosis (a), and dermatitis (d) are observed in the epithelium. H\&E, obj. 20.

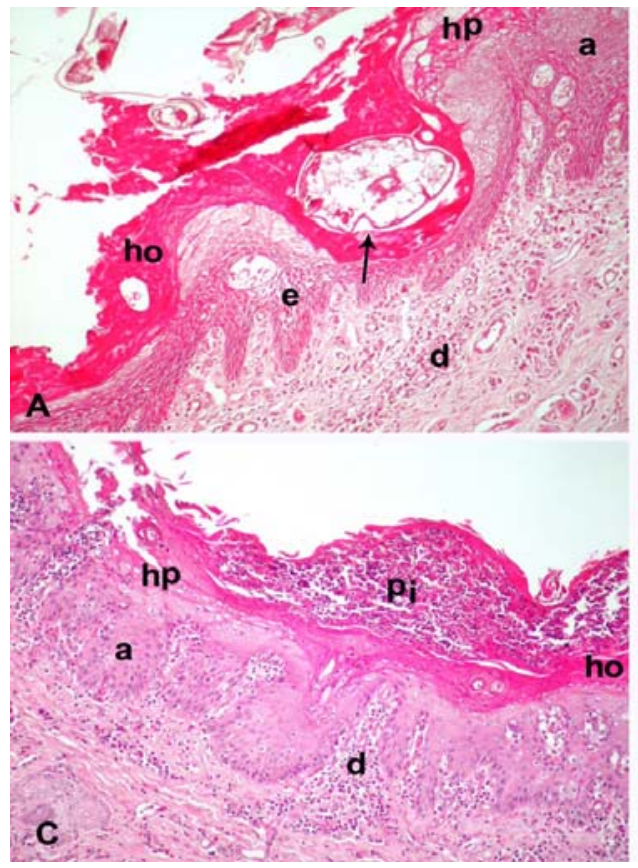

Source: Elaboration of the authors.

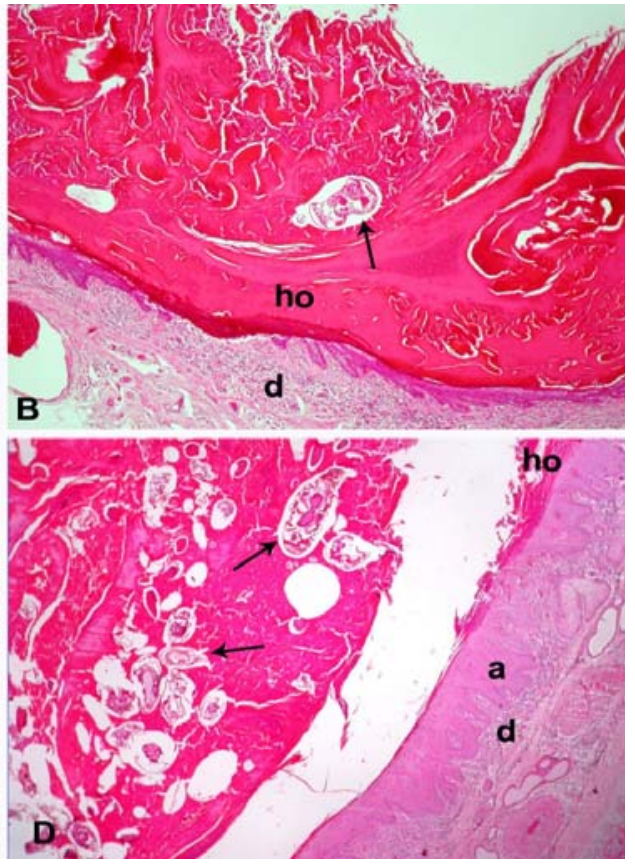

In this study, the absence of eosinophils in the histological lesions of most of the animals, suggests that there is not a hypersensitivity reaction occurring. In contrast, in bovine and ovine scabies induced by Psoroptes ovis, the salivary proteinases and secretions of the parasite cause hypersensitivity with intense inflammation and eosinophilic infiltration, characterizing an allergic dermatitis (STROMBERG et al., 1986; SINCLAIR; KIRKWOOD, 1983; BURGESS et al., 2010). However, the absence of an eosinophilic reaction and the presence of a mixed inflammatory infiltrate, composed by neutrophils, macrophages, lymphocytes, and plasma cells, might represent the action of secondary bacterial infection and/or the progression to a chronic hypersensitivity reaction. Furthermore, in ovine scabies, lesions from auto traumatisms occur as a consequence of the itching that is due to a hypersensitivity reaction, while in psoroptic mange in goats, because the infestation does not present itching, most cases are asymptomatic or only present exudate with the formation of a crusty material, which does not extend beyond the ear. In the otocariasis caused by $P$. cuniculi the histological lesions observed suggest a mechanical effect due to the presence of the mites that together with the cerumen, exudate, and residues of keratin form a mass that obstructs the auditory canal. In contrast to what occurs in goats, $P$. cuniculi in rabbits causes macroscopic and histological alterations with the presence of severe ulcerative and inflammatory lesions in the skin (TEHRANI et al., 2011). 


\section{References}

BURGESS, S. T. G.; FREW, D.; NUNN, F.; WATKINS, C. A.; MCNEILLY, T. N.; NISBET, A. J.; HUNTLEY, J.

F. Transcriptomic analysis of the temporal host response to skin infestation with the ectoparasitic mite Psoroptes ovis. BMC Genomics, London, v. 11, p. 624, 2010. Available at: $<$ http://www.biomedcentral.com/14712164/11/624>. Accessed at: 30 mar. 2015.

COSTA, C. A. F.; VIEIRA, L. S. Ectoparasitos permanentes em caprinos e ovinos em Sobral, CE. Pesquisa Agropecuária Brasileira, Brasília, v. 19, n. 5, p. 639-646, 1984.

FACCINI, J. L. H.; LIGNON, G. B.; LEITE, R. C. Otocaríase psoróptica dos caprinos. Infestações subclínica. Pesquisa Agropecuária Brasileira, Brasília, v. 16, n. 5 , p. $725-726,1981$.

FERRY, F. R.; FACCINI, J. L. H.; INADA, T. The role of ear mites of the genus Raillietia (Acari: Railletidae) in otitis of domestic ruminants. Pesquisa Veterinária Brasileira, Seropédica, v. 31, n. 11, p. 981-984, 2011.

FRIEL, J.; GREINER, E. C. Ear mites from domestic goats in Florida. Experimental and Applied Acarology, Atlanta, v. 4, n. 4, p. 345-351, 1988.

HEATH, A. C. G.; BISHOP, D.; TENQUIST, J. D. The prevalence and pathogenity of Chorioptes bovis (Hering, 1845) and Psoroptes cuniculli (Delafond, 1859) (Acari: psoroptidae) infestations in feral goats in New Zealand. Veterinary Parasitology, Amsterdam, v. 13, n. 2, p. 159169, 1983.

LITTLEJOHN, A. I. Psorotic mange in the Goat. Veterinary Record, London, v. 10, n. 3, p. 148-155, 1968.

LOFSTEDT, J.; WHITE, D.; GARLICK, D. S.; HANNA, P. Severe psoroptic mange and endoparasitism in a Nubian doe. Canadian Veterinary Journal, Guelph, v. 35, n. 11, p. 716-718, 1994.

MUNRO, G. S.; MUNRO, H. M. C. Psoroptes mange in goats in Fiji. Tropical Animal Health and Production, Amsterdam, v. 2, n. 1, p. 1-5, 1980.
NUNES, V. S.; NUNES, I. J. Técnica de exame postmortem do sistema auditivo aplicada ao estudo de otites em bovinos. Arquivos da Escola de Veterinária, Belo Horizonte, v. 27, n. 2, p. 155-161, 1975.

PERRUCCI, S.; CASTELlA, A.; BENCINI, E.; MACCHIONI, F. Clinical and etiological aspects of goat ear mite infestations in Tuscany. Parassitologia, Roma, v. 38, n. 3, p. 549-553, 1996.

SANTOS, A. C. G.; SANTOS, S. B.; GUERRA, R. M. N. Artropodes parasitas de caprinos do sertão paraibano. Agropecuária Científica no Semiárido, Patos, v. 2, n. 1, p. 9-17, 2002.

SINCLAIR, A. N.; KIRKWOOD, A. G. Feeding behaviour of Psoroptes ovis. Veterinary Record, London, v. 112, n.3, p. 65-72, 1983.

STROMBERG, P. C.; FISHER, W. F.; GUILLOT, F. S.; PRUETT, J. H.; PRICE, R. E.; GREEN, R. A. Systemic pathologic responses in experimental Psoroptes infestation of Hereford calves. American Journal Veterinary Research, Washington, DC, v. 47, n. 7, p. 1326-1331, 1986.

SWEATMAN, G. K. On the life history and valididy of the species in Psoroptes, a genus of mange mites. Canadian Journal of Zoology, Ottawa, v. 36, n. 6, p. 90529, 1958.

TEHRANI, A. A.; SADEGHIAN, S.; JAVANBAKHT, J.; IMANI, A.; SADEGHZADEH, S. Studies of clinical and histopathological lesions resulting from Psoroptes cuniculi mange in domestic rabbits. Biochemical and Cellular Archives, New Delhi, v. 11, n. 1, p. 221-226, 2011.

YERUHAM, I.; HADANI, A.; ROSEN, S. Psoroptes ear mange (Psoroptes cuniculi, Delafond, 1856) domestic and wild ruminant in Israel. Veterinary Parasitology, Amsterdam, v. 17, n. 4, p. 345-353, 1985. 
